\title{
DETERMINATION OF MELATONIN IN BATS GUANO SEDIMENTS BY HPLC COUPLED WITH FLUORESCENCE DETECTION: MELATONIN AS AN ADJUVANT TREATMENT OF COVID-19
}

\author{
A. H. Hamdani ${ }^{1, \bowtie}$, H. Johanes ${ }^{1}$, M. Faisal ${ }^{1}$ and NH. Rina ${ }^{2}$ \\ ${ }^{1}$ Department of Geochemistry, Faculty of Geology, University of Padjadjaran, \\ Bandung 45360, Indonesia \\ ${ }^{2}$ Pharmacist, Amanah Education Foundation, Bandung, Indonesia, 40293 \\ ${ }^{\square}$ Corresponding Author: ahmad.helman@unpad.ac.id
}

\begin{abstract}
Research related to geological materials that are useful for health in Indonesia (bio-geo-prospective) for health is still being developed. This article opens a new perspective on the possibility of using melatonin in bats guano rock in attenuating COVID-19 based on the prospect of its occurrence. The current outbreak of the COVID-19 virus is a pandemic that has infected hundreds of thousands of patients worldwide which certainly requires good medication. To determine the presence of bioactive chemicals in sediment rocks both qualitatively (types) and quantitatively (levels) can be done by analyzing the active compounds (compounds (chemical compounds that have medicinal properties). While obtaining these active compounds can be done by isolating the active compounds. The isolated pure compound can be further developed into modern medicine. A sensitive and validated method for the melatonin determination by developed High-performance liquid chromatography (HPLC) coupled with fluorescence detection with an extraction procedure of direct sample extraction (DSE) in measure melatonin levels in bats guano rock. The test validation shows that the use of this method is very successful as indicated by the high correlation coefficient value of 0.9997 , the RSDs $(\mathrm{n}=3)$ of $4.35 \%$ and the LOD values is 0.0236 (ng / $\mathrm{g} \mathrm{FW)} \mathrm{and} \mathrm{LOQ} 0.1283$ (ng / $\mathrm{g} \mathrm{FW).}$ The average melatonin content in guano stones was $24+0.18 \mathrm{ng} / \mathrm{g} \mathrm{FW}$.

Keywords: Melatonin, Bats Guano Sediment, HPLC, Fluorescence Detection, Direct Sample Extraction.

RASĀYAN J. Chem., Vol. 14, No.2, 2021
\end{abstract}

\section{INTRODUCTION}

In recent history, the Covid-19 pandemic outbreak that occurred at this time was the most devastating health disaster and greatly affects all human life. The recent outbreak was discovered in Wuhan, China in early December 2019; the outbreak is very fast spreading not only in China but also throughout the world..$^{1-3}$ The outbreak is caused by the coronavirus (CoVs), this virus is a virus that has ribonucleic acid (RNA) as its genetic material that can infect animals and humans; the infection that occurs will disrupt the central nervous system, respiratory system and infections of the gastrointestinal tract. ${ }^{4}$

Coronaviruses can be classified into four main groups known as alpha, beta, gamma, and delta. It is currently known that there are seven types of coronavirus that are known to infect people, some of which are more common or more severe than others.

At this time it is believed that Order Chiroptera, suborders Megachiroptera, Microchiroptera, and genus Rhinolophus of Bats Family are carriers of coronaviruses that infect humans. ${ }^{5,6}$ However, how the transmission occurs is not clear, it is still at the level of a hypothesis. ${ }^{7}$

Based on several studies on guano bats, it is known that bats are a habitat for several pathogenic microbes, including viruses ${ }^{8}$, fungi ${ }^{9}$, and bacteria. ${ }^{10}$ However, research on the content of melatonin as a chemical compound on bat guano sediment that can treat Covid-19 has not been done much. The results showed that the melatonin content in bats was greater than that found in humans.

Numerous studies have shown that melatonin concentrations in bats show significant variations at night and during the day; melatonin concentrations of 60 to $500 \mathrm{pg} / \mathrm{ml}$ at night and during the day are still at high 
levels of 20-90 pg / $\mathrm{ml}$ depending on the species. ${ }^{11,12}$ To compare melatonin levels in humans; it was observed in the young population at the level of $83+/-20 \mathrm{pg} / \mathrm{ml}$, but in the older adult population at the level of $11.2+/-1.6 \mathrm{pg} / \mathrm{ml} .^{13}$

Documentation from several studies shows that melatonin has a positive effect that can be alleviating disorders of the respiratory system due to bacteria, radiation, and viruses. ${ }^{14,15}$ They reported that there is evidence that pneumonia caused by Coronaviruses (CoVs) such as acute lung injury (ALI) and acute respiratory distress syndrome (ARDS) by adding melatonin as a supportive adjuvant utility in treating the diseases. ${ }^{16,17}$

Melatonin can be found in humans, animals and plants, ${ }^{18}$ in humans, more melatonic content is found in young children than their parents and even their grandparents. Whereas in animals, melatonic is found mostly in bats, exceeding the content in humans. ${ }^{19,20}$

Melatonin (N-acetyl-5-methoxytryptamine) (Fig.-1), since being isolated and identified in vertebrates, ${ }^{21}$ is a pineal-related hormone related to pineal, besides the important role in regulating the circadian and seasonal biological rhythm; antioxidant, cytoprotection, anti-inflammatory, and an immunostimulant. ${ }^{22}$<smiles>COc1ccc2[nH]cc(CCNC(C)=O)c2c1</smiles>

Fig.-1: Melatonin's Chemical Structure ((N-acetyl-5-methoxytryptamine)

Various analytical techniques by HPLC have been used to determine melatonin levels, indicated low concentration in some biological samples, such as in blood plasma, ${ }^{23-25}$ in plant, ${ }^{26}$ in medicine ${ }^{27}$ and urine. ${ }^{28}$ However, research on melatonin levels in sediments (geological materials) samples has not been widely carried out. Referring to the low concentration of melatonin and the coexistence of several endogenous compounds in biological samples; an HPLC coupled fluorescence detection was used to be the method of choice of analysis to determine the presence of melatonin in geological samples ( bats guano sediments).

\section{Material and Methods}

\section{EXPERIMENTAL}

\section{Bat guano material.}

The samples of bat guano sediments were taken from Giriharjo Cave and Ngrandu Cave in Gunungkidul Regency, East Java, Indonesia. To sterilize the guano bat material, $10 \%$ hypochlorous acid solution is given for 5 minutes, then washed with distilled water three times, and soaked in distilled water for 24 hours at a temperature of $24^{0} \mathrm{C}$.

\section{Reagents}

Melatonin CAS 73-31-4 - (Merck), Chloroform, Ethyl acetate (Merck), Acetonitrile (Merck).

\section{Sample Preparation}

The direct-sample extraction (DSE) was used in the sediments extraction processes in sediments $(1.0 \mathrm{~g}$ fresh The direct-sample extraction (DSE) was used in the sediment extraction processes in sediments. The amount of $1.0 \mathrm{~g}$ fresh weight $(\mathrm{FW})$ was ground to be powdered and put in a $15 \mathrm{~mL}$ vials together ethyl acetate $(3 \mathrm{~mL})$ and the mixture was immersed for 30 minutes in an ultrasonic bath. After leaving it for 15 hours at $4^{0} \mathrm{C}$. All the organic solvent extracts were combined, then evaporated to dryness. Furthermore, using $0.5 \mathrm{ml}$ acetonitrile the residue was redissolved, and filtered by $0.2 \mu \mathrm{m}$. Finally analyzed by HPLC with fluorescence detection. 
The concentrations of the standard melatonin solution consisted of $0.01,0.1$, and $1 \mu \mathrm{M}$ was prepared similar to the above samples processes.

\section{HPLC with Fluorescence Detection}

Agilent HPLC Agilent 1260 Infinity Fluorescence Detector with the addition of an Eclipse-XDB-C18 column $(4.6 \times 150 \mathrm{~mm}, 5 \mu \mathrm{m})$ was employed. Fluorescence Detector (FLD) was performed with an excitation wavelength of $280 \mathrm{~nm}$ and an emission wavelength of $350 \mathrm{~nm}$ and a run time 20 minutes. The mobile phase consists of the isocratic procedure, $50 \%$ acetonitrile, and $50 \%$ water. The injection volume was $20 \mu \mathrm{L}$, and the flow rate of $0.2 \mathrm{~mL} / \mathrm{min}$. The column temperature was set at $40{ }^{\circ} \mathrm{C}$.

\section{RESULTS AND DISCUSSION}

A preliminary test of melatonin analysis was carried out to determine the retention time of the compound. For detecting melatonin by fluorescence detection, we used $\lambda$ exc of $280 \mathrm{~nm}$ and a $\lambda$ emi of $350 \mathrm{~nm}$; the chromatogram peak of melatonin standard solution can be seen at the retention time $15.5 \mathrm{~min}$ as shown in Fig.-2 (left), whereas the chromatogram peak of the bat guano sample was seen in Fig.-2 (right).

\section{Validation of Melatonin Identification Analysis Methods \\ Linearity Test}

The linearity of the melatonin determination method by HPLC is determined by making a curve of the relationship between the standard concentration (X-axis) and the peak area (Y-axis). The relationship between the melatonin injected $(2-231 \mathrm{pg})$ and the mean area was reflected in the linear regression equation and the correlation coefficient ( $\mathrm{r}$ ). Based on the test results, the $\mathrm{R}^{2}$ - value for the standard melatonin was 0.9999. The linear regression equation for the standard melatonin curve is $\mathrm{Y}=2.009 \mathrm{x}+1.213$ (Fig.-3, Table-1). A small intercept value (close to zero) indicates that there is no disturbance from the matrix in the solution so that the determination of the sample analysis can be analyzed properly.

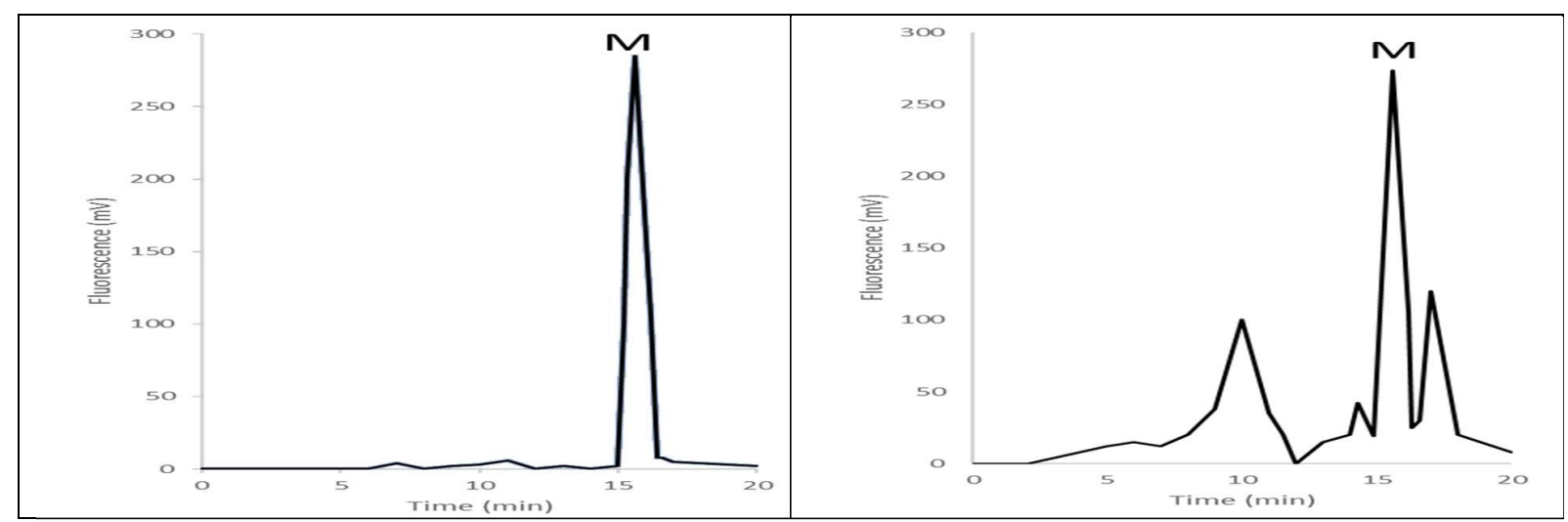

Fig.-2: Chromatogram of Melatonin Standard ( 2 pmol; left) and Melatonin extracted from $2 \mathrm{ml}$ of a Plasma Sample (right), by HPLC with Fluorescence Detector

\section{Precision}

To determine the level of precision, repeated measurements were carried out 5 times with different concentrations. The value of precision is reflected in the relative standard deviation (RSD). The RSD melatonin value from this study is $0.37 \%$. less than $2 \%$. The RSD value based on the analysis of the concentration of melatonin is $0.37 \%$. The low RSD values $(<2 \%)$ reflecting the high degree of precision.

\section{Accuracy (Recovery)}

To find out whether the analytical method used has good accuracy and precision, the addition of the standard melatonin concentration either in the working standard solution or rock samples is carried out. From the research, it was found that the percent recovery range for the addition of raw melatonin was 90.5603$100.0430 \%$ (mean of recovery $94.5775 \%$ ) with the RSD obtained of $3.6652 \%$. The percent recovery range 
RASĀYAN J. Chem.

Vol. 14 | No. 2 |1116-1120| April - June | 2021

and coefficient of variation $(<15 \%)$ meet the required criteria, so it is evident that the analytical method used has good accuracy and precision.

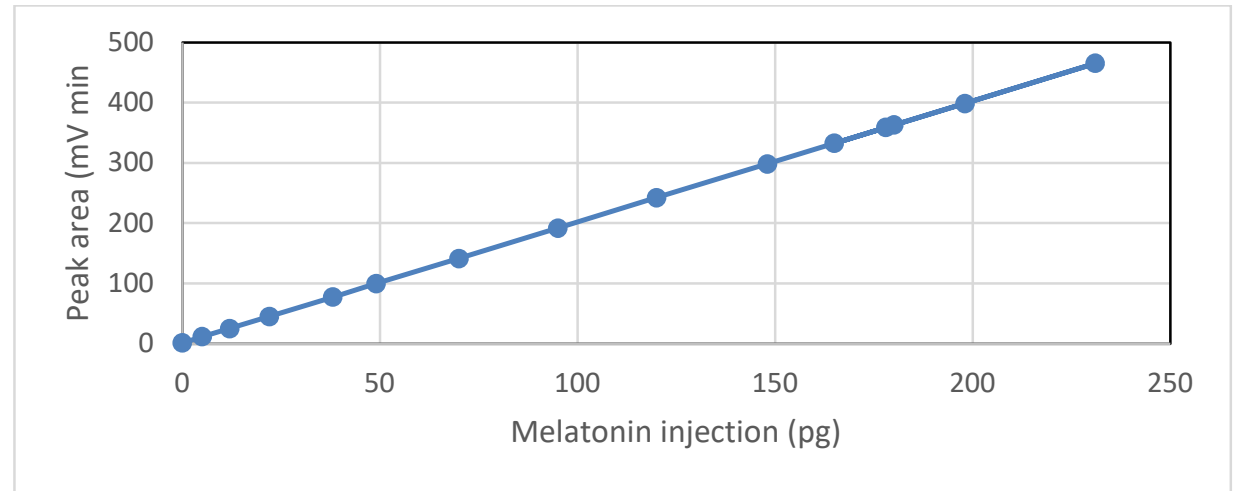

Fig.-3: Melatonin Standard Linear Regression Curve

Table-1: Linearity Statistical Summary of Melatonin

\begin{tabular}{c|c}
\hline \multicolumn{2}{c}{ Regression Statistics } \\
\hline Intercept & 1.213949598 \\
\hline Slope & 2.009126245 \\
\hline R square & 0.999999991 \\
\hline Standard Deviation & 0.015582096 \\
\hline
\end{tabular}

The Limit of Detection and Limit of Quantification

The limit of detection (LOD) and Limit of quantification (LOQ) are calculated from a linear regression curve which uses the ratio between the standard deviation of response and the slope of the calibration curve. By using the different multiplier factors ( 3.3 for LOD and 10 for LOQ). The LOD values is 0.0236 (ng/g FW) and LOQ 0.1283 (ng/g FW).

\section{Melatonin levels}

The level of melatonin in different concentrations directly related to the respective recovery rate of each extraction. The level of efficiency around $10-15 \%$. The mean melatonin levels obtained by using the DSE method on bat guano sediment is $24+0.18 \mathrm{ng} / \mathrm{g} \mathrm{FW}$.

\section{CONCLUSION}

The results of the validation tests, which include linearity, precision, and low LOD and LOQ values below the allowable, indicate that the HPLC coupled detection analysis method used following the Direct sample extraction procedure is very good.

\section{ACKNOWLEDGEMENT}

The authors are grateful for the funding from the University Padjadjaran Research Programme of the RPDP of the year 2020. The authors also would like to acknowledge the Dean of Faculty of Geology for their support to establish this article.

\section{REFERENCES}

1. C. Huang, Y. Wang, X. Li, L. Ren, J. Zhao, Y. Hu, L. Zhang, G. Fan, J. Xu, X. Gu, Z. Cheng, T. Yu, J.Xia, Y.Wei, W.Wu, X.Xie, W.Yin, H. Li, M. Liu, Y. Xiao, H. Gao, L. Guo, J. Xie, G. Wang, R. Jiang, Z. Gao, Q. Jin, J. Wang, B. Cao, Lancet, 395, 497(2020), DOI:10.1016/S0140-6736(20)30183-5

2. N. Zhu, D. Zhang, W. Wang, X. Li , B. Yang, J. Song, X. Zhao, B. Huang, W. Shi, R. Lu, P. Niu, F. Zhan, X. Ma, D. Wang, W. Xu, G. Wu, GF. Gao, W. Tan, New England. Journal of Medicine, 382, 727(2020), DOI:10.1056/NEJMoa2001017

3. A. L. Phelan, R. Katz, L.O. Gostin, JAMA, 323(8), 709(2020), DOI:10.1001/jama.2020.1097 
RASĀYAN J. Chem.

Vol. 14 | No. 2 |1116-1120| April - June | 2021

4. C. H. Calisher, J. E. Childs, Clinical Microbiology Reviews, 19, 531(2006), DOI:10. 1128/CMR.00017-06

5. A. C. P. Wong, X. Li, K. P. S. Lau, C.Y. Patrick, Viruses, 11, 174(2019), DOI:10.3390/v11020174

6. C. R. Parrish, E. C. Holmes, D. M. Morens, E. C. Park, D. S. Burke, C. H. Calisher, C. A. Laughlin, L. J. Saif, and P. Daszak Microbiology and Molecular Biology Reviews, 72(3), 457(2008), DOI:10.1128/MMBR.00004-08

7. Y. Fan, K. Zhao, Z. L. Shi, P. Zhou, Viruses, 11, 210(2019), DOI:10.3390/v11030210

8. L. F. Wang and B. Eaton, The Biology, Circumstances and Consequences of Cross-species Transmission, eds J. E. Childs, J. S. Mackenzie, and J. A. Richt (New York, NY: Springer), 325 (2007)

9. W.Y. Mok, R. C. Luizão, and M. S. Barreto da Silva., Applied Environmental Microbiology. 44, 570(1982), DOI: 10.1128/aem.44.3.570-575.1982

10. S. Banskar, S. S. Bhute, M.V. Suryavanshi, S. Punekar, and Y. S. Shouche, Scientific Report, 6, 36948(2016), DOI:10.1038/srep36948

11. R. D. Heideman, K. R. Bhatnagar, F. Hilton, Journal of Pineal Research, 20, 90(1996), DOI: 10.1111/j.1600-079X.1996.tb00245.X

12. C. Haldar, R. Yadav, Alipreeta, Molecular and Integrative Physiology, 144, 95(2016), DOI:10.1016/j.cbpa.2006.02.041.23

13. H Iguchi, K. I. Kato, H. Ibayashi., The Journal of Clinical Endocrinology \& Metabolism, 55, 27(1982), DOI: $10.1210 /$ jcem-55-1-27

14. N. S. Foulkes, J. Borjigin , S. H. Snyder and C. P. Sassone, Trends Neuroscience, 20, 487(1997), DOI: 10.1016/s0166-2236(97)01109-0

15. J. Cui, F. Li, Shi, Nature Review Microbiology, 17, 181(2019), DOI:10.1038/s41579-018-0118-9

16. X. Wu, H. Ji, Y. Wang, C. Gu, W. Gu, L. Hu, L. Zhu, Oxidative Medicine Cellular Longevity, 4087298 (2019), DOI:10.1155/2019/4087298. eCollection 2019

17. Y. Zhang, X. Li, J. J. Grailer, Journal of Pineal Research. 60, 405(2016), DOI:10.1111/jpi.12322

18. P. K. Pal, A. Chattopadhyay, D. Bandyopadhyay, Melatonin Research. 3(3), 417(2020), DOI: $10.32794 / \mathrm{mr} 11250070$

19. R. M. Scholtens, B. C. V. Munster, M. F. V. Kempen, Journal of Psychosomatic Research.,86, 20 (2016), DOI:10.1016/j.jpsychores.2016.05.005

20. S. Bahare, S. Farukh, V. Patrick, K. Agnieszka, D. J. Lilian, T. Kathryn, S. R. Javad, MP. Malgorzata, M. Miquel, M. Natália, I. Marcello, Cells, 8, 681(2019), DOI:10.3390/cells8070681

21. Waldhauser F, Weiszenbacher G, Tatzer E, The Journal of Clinical Endocrinology \& Metabolism, 66,648(1988), DOI: 10.1210/jcem-66-3-648

22. A. B. Lerner, J. D. Case, Y. Takahashi, T. Lee, W. Mori. Journal of the American. Chemical Society, 80(10), 2587(1998), DOI:10.1021/ja01543a060

23. J. F. Peniston, U. D. Wei, A. S. Catherine, A. Kadva, A. M. Stalteri, and R. E. Silman, Clinical Chemistry, 39(11), 2242(1993), DOI:10.1093/clinchem/39.11.2242

24. E. Bechgaard , K. Lindhardt, L. Martinsen, Journal of Chromatography B Biomedical Sciences and Application, 712, 177(1998).

25. T. Tomita, K. Hamase , H. Hayashi, H. Fukuda, J. Hirano, K. Zaitsu, Analytical Biochemical, 316, 154(2003), DOI:10.1016/s0003-2697(03)00079-4

26. M. B. Arnao and J. R. Hernández, Phytochemical Analysis, 20, 14(2009), DOI:10.1002/pca.1083

27. J. Lin, Z. Chunchan, G. Yaoxiang, Z. Xiaojun, L. Xican, Spatula Drug Discovery, 2(3), 147(2012), DOI: $10.5455 /$ spatula.20120906112559

28. E. A. Almeida, P. D. Mascio, T. Harumi, D. W. Spence, A. Moscovitch, R. Hardeland, D. P. Cardinali, M. G. M. Brown, S. R. P. Perumal, Child's Nervous System, 27, 879(2011), DOI:10.1007/s00381010-1278-8

29. L. Huber, Validation and Qualification in Analytical, Laboratories, Interpharm Press, East Englewood, CO, USA, 1998.

[RJC-6199/2020] 